\title{
A LIST OF PLANTS COLLECTED BY THE CORNELL PARTY ON THE PEARY VOYAGE OF 1896.
}

W. W. ROWLEE and K. M. WIEGAND.

THRough the generosity of Mr. E.G. Wyckoff it was arranged that a party of Cornell professors and students representing the geological department of the University should accompany Lieutenant Peary upon his trip to northwest Greenland during the summer of 1896 . The party was organized by Professor R. S. Tarr. At first he contemplated inviting a professional botanist to accompany him; but later, largely on account of the additional expense which this course would naturally cause, he decided to abandon this part of the enterprise and depend entirely upon his own assistants for the collection of botanical material. Considering that the main object of the expedition was geological rather than botanical study, the success from a botanical standpoint is surprising. In all about one hundred and thirty-five species and varieties of spermatophytes were collected, and the interesting series of specimens representing Brown's arctic willow (Salix Gronlandica) gives positive testimony of the zeal and success with which the party studied the flora of the places where they stopped.' The collection from the Nugsuak peninsula is perhaps the most complete yet secured by an American expedition.

The first collection was made at Turnavik island on the Labrador coast July 20th. Some collections were made at Big island along the northern shore of Hudson strait, and at White strait, Baffin's land, July $25^{\text {th }}$ to 27 th. Godhavn upon the island of Disco was visited August $2 \mathrm{~d}$ and $3 \mathrm{~d}$, and finally the main collecting ground of the trip, the Nugsuak peninsula, situated in lat. $74^{\circ} \mathrm{I} 5^{\prime}$, was reached August 7 th. There in three camping places the party remained until September 7 th. Of

${ }^{x}$ Professor Tarr was aided in this work by J. O. Martin, who did by far the greater part of the purely botanical work. 
the three camps given in the list of localities Camp I was near Wilcox head and near the open sea, Camp 2 was midway between the open sea and the ice front, and Camp 3 was near the ice front. It was from Camp 3 that excursions were made to the Devil's Thumb and to Mt. Schurman. ${ }^{2}$ The latter, about seven miles inland from the ice front, is a mountain covered with ice except its summit. From the observations made by the party it seems certain that this mountain top was recently entirely covered by the ice cap. It is interesting on this account to notice the plants that have found their way to the mountain. This is the list:

\section{Savastana alpina \\ Carex Bigelovii \\ Juncoides hyperboreum \\ Papaver alpinum \\ Cardamine bellidifolia}

\section{Potentilla emarginata \\ Cassiope tetragona \\ Vaccinium uliginosum microphyllum \\ Antennaria alpina}

These are all perennial plants. In every case but few specimens of each species were seen, although all are abundant along the Greenland coast and for the most part throughout the arctic regions. Antennaria is the only one with appendages upon the fruit for wind dissemination, and Vaccinium alone has fleshy fruits. All have minute seeds. The cliffs of the mountains are favorite nesting places for birds, and no doubt they carry seeds across the ice and leave them upon the mountain. Such as have the hardiness to do so germinate and maintain themselves, all others perish.

PLANTS COLLECTED IN LABRADOR AND BAFFIN'S LAND.

Phippsia algida (Soland.) R. Br. Turnavik; Big island.

Savastana alpina (Sw.) Scribn. Turnavik; Big island.

Trisetum subspicatum (L) Beauv. Big island.

Elymus arenarius L. Cumberland sound.

Carex brunnescens (Pers.) Poir. Turnavik.

Carex glareosa Wahl. Turnavik.

Specimens much larger than those from Greenland.

${ }^{2}$ A map of the region about the Nugsuak peninsula will be found. Bull. Geol. Soc. Am. $8: 25 \mathrm{I}-268$. 1897 . 
Carex membranopacta Bailey. Big island.

Carex Bigelovii Torrey. Big island.

Carex sp. Turnavik island.

A form differing from C. Bigelovii in having comparatively shorter narrower leaves, less sheathing at the base of the stem; rootstocks more slender; staminate spikes commonly two (rarely only one) $8-15^{\mathrm{mm}}$ long, approximate, acute; pistillate commonly solitary (rarely two), $\mathrm{I}^{\mathrm{mm}}$ distant from the staminate ( $10-15^{\mathrm{mm}}$ long), acute; perigynia obovoid, obtuse, granulate, completely covered by the black scale.

Carex rariflora J. E. Smith. Turnavik.

Carex saxatilis $\mathrm{L}$. Turnavik.

Eriophorum vaginatum $\mathrm{L}$. Turnavik.

Eriophorum Scheuchzeri Hoppe. Big island.

Scirpus caspitosus L. Turnavik.

Juncoides hyperboreum (R. Br.) Sheldon. Big island.

Iris Hookeri Penny. Turnavik.

Salix arctica diplodictya (Traut.) And. Big island.

Mr. Bebb considered the two species of Dr. Trautvetter (S.diplodictya and $S$. (rassijulis) as confluent. Andersson makes them varieties, and uses Trautvetter's names for them. The characters of our plants certainly correspond to those given in Trautvetter's description of S. diplodictya. However, until more evidence can be accumulated it may be well to follow Andersson's conservative arrangement and consider them as varieties. We have not seen Dr. Bell's plant from Cape Prince of Wales, Hudson strait. Lange includes this variety in the Flora Gronlandica and says of it "formas transitorias inter $S$. arctica Pall. et $S$. Gronlandica (And.) Lundstr." So far as we have seen specimens the species are quite distinct.

Salix Uva-Ursi Pursh. White strait.

Two quite distinct forms were collected: Form $a$, with depressed stems, very short-peduncled aments, and elliptic-obovate very short petioled leaves $5-6^{\mathrm{mm}}$ long by $3-4^{\mathrm{mm}}$ wide, rounded at the apex and distinctly crenate-serrulate. Form $b$, with less depressed stems; peduncles relatively long, bearing three to four scattered leaves smaller than the leaves of the sterile shoots, aments more loosely flowered; leaves spatulate, distinctly petioled, $10-12^{\mathrm{mm}}$ long by $3^{-5^{\mathrm{mm}}}$ wide, very indistinctly serrulate or entire, acute at the apex.

Salix Gronlandica (And.) Lundstr. Turnavik; Big island; Baffin's land.

Salix herbacea L. Big island. 
Salix reticulata $\mathrm{L}$. Big island.

Apparently rare; only the pistillate plants were collected.

Polygonum viviparum L. Turnavik; Big island.

Silene acaulis L. Turnavik; White strait.

Melandrium apetalum (L.) Fzl. Big island.

Alsine longipes (Goldie) Coville. Turnavik.

Cerastium alpinum L. (var. lanatum Lindbl.) White strait; Turnavik; Big island.

Ranunculus nivalis L. Big island.

Papaver arcticum L. White strait; Big island.

Draba Fladnizensis Wulf. (D. Wahlenbergii heterotricha Lindbl.). Big island.

Draba alpina L. White strait.

Leaves $\mathrm{I}^{\mathrm{cm}}$ long, spatulate, densely hirsute with forked hairs; scapes $5^{\mathrm{cm}}$ high; flowers racemose, petals pale yellow, twice the length of the calyx; elliptic pods, calyx and scapes hirsute with forked hairs.

Draba algida Adams. White strait; Big island.

Our plants are quite distinct from D. alpina; leaves large, $2-2.5^{\mathrm{cm}}$ long, spatulate and very flaccid, nearly glabrous, except some marginal hairs toward the base; scapes scarcely longer than the leaves, finely pubescent with forked hairs; petals twice the length of the calyx, deep yellow; calyx and pods glabrous.

Cochlearia Grenlandica L. Turnavik.

Cardamine bellidifolia L. White strait.

Sedum roseum (L.) Scop. Turnavik.

Saxifraga cernua L. Big island; Turnavik.

Saxifraga rivularis $\mathrm{L}$. Big island.

Saxifraga caspitosa L. Big island.

Saxifraga tricuspidata Retz. White strait.

Saxifraga oppositifolia L. White strait.

Rubus arcticus L. Turnavik.

Rubus Chamaemorus L. Turnavik.

Potentilla nana Willd. White strait.

Potentilla tridentata L. Turnavik.

Dryas integrifolia M. Vahl. White strait.

Lathyrus maritimus Aleuticus Greene (White, Bull. Torr. Bot. Club 2r : 430. I894). Turnavik. 
Many arctic and Alaskan specimens usually referred to L. maritimus are quite different from the more southern plants. There is some doubt, however, as to whether they should be considered as forming a distinct species. The Alaskan plants have been well described in the above cited article as var. Aleuticus Greene. Our material from Labrador agrees in every particular with this description, and is identical with the specimen in the Columbia University Herbarium cited by Mr. White, which we have carefully studied. This variety is characterized by a low and very slender stature; stem and lower surface of the leaves hairy; the latter smaller than in the type ( $1.5-3^{\mathrm{cm}}$ long), elliptical, acute, and not prominently veined.

Empetrum nigrum L. Turnavik.

Chamaenerium latifolium (L.) Sweet. White strait.

Cornus Suecica L. Turnavik.

Pyrola rotundifolia pumila Hornem. Big island.

Ledum palustre L. Big island; Turnavik.

Ledum Gronlandicum CEder. Turnavik.

Kalmia glauca Ait. Turnavik.

Phyllodoce carulea (L.) G. \&. G. Turnavik.

Cassiope tetragona (L.) Don. White strait; Big island.

Cassiope hypnoides (L.) Don. Big island.

Chamacistus procumbens (L.) Kuntze. Turnavik; Big island.

Vaccinium uliginosum microphyllum Lge. Turnavik; White strait.

Vaccinium Vitis-Idea L. Turnavik.

Diapensia Lapponica L. Turnavik; Baffin's land.

Menyanthes trifoliata L. Turnavik.

Castilleia pallida septentrionalis Gray. Turnavik.

Pedicularis hirsuta L. White strait; Big island.

Pedicularis lanata (Willd.) Cham. Big island.

Pinguicula vulgaris L. Turnavik.

Plantago maritima L. Turnavik.

Lonicera canulea L. Turnavik.

Solidago Virgaurea L. Turnavik.

PLANTS COLLECTED ON THE WEST COAST OF GREENLAND.

Alopecurus alpinus Smith. Camp 3; Wilcox head.

Found mostly where Esquimaux have camped. Probably transported from place to place by them. 
Phippsia algida (Soland.) R. Br. Nugsuak peninsula.

Savastana alpina (Sw.) Scribn. Camp 2; Mt. Schurman; Camp 3.

A few isolated spears only were found on Mt. Schurman.

Trisetum subspicatum (L.) Beauv. Disco island.

Poa alpina L. Godhavn, Disco ; Camp 3 ; Wilcox head.

Poa flexuosa Wahl. Godhavn, Disco; Camps 2 and 3; Wilcox head; Devil's Thumb. Quite common on Disco island and at Camp 3 .

A large and small form occurs; the taller according to Mr. Martin grows in gull's droppings, especially in shady places. It has been described as sula.

Poa flexuosa elongata Blytt. Nunatak no. I ; Nugsuak penin-

Festuca duriuscula L. Godhavn, Disco.

Atropis vilfoidea (And.) Row. \& Wieg. n. nom. (Catabrosa vilfoidea And. Vet. Akad. Forh. 254. I862.) (Glyceria vilfoidea Th. Fr. Kgl. Vet. Akad. Ofv. I39. I869.) Wilcox head.

Carex glareosa Wahl. Devil's Thumb.

Carex lagopina Wahl. Godhavn, Disco.

Carex nardina Fries. Nunatak no. I; Nugsuak peninsula; Disco island.

Carex capitata L. Godhavn, Disco.

Carex Bigelovii Torr. Godhavn, Disco ; Camp 2; Mt. Schurman; Devil's Thumb; Nugsuak peninsula.

Carex rigida Good. Camp 3.

Carex stans Drej. Wilcox head.

Carex rariflora J. E. Smith. Found growing in Sphagnum on a hillside on Disco island.

Carex scirpoidea Michx. Nunatak no. I and Camp 2 Nugsuak peninsula.

Eriophorum Scheuchzeri Hoppe. Wilcox head; Camp 2; Godhavn, Disco.

Juncus trifidus L. Godhavn, Disco.

Juncoides parviflorum (Ehrh.) Coville (var. fastigiata Buch.), Godhavn, Disco.

Juncoides spicatum (L.) Kuntze. Disco island. 
Juncoides hyperboreum (R. Br.) Sheldon. Disco island; Camps 2 and 3 ; Wilcox head; Mt. Schurman; Nunatak no I.

Juncoides nivale (Laest.) Coville. Camps 2 and 3.

Our specimens are Luzula arctica of Lange's Flora Gronlandica, characterized as having leaves long acuminate, and seem to agree with Læstadius' description of $L$. campestris var. nivalis, but differ from Buchenau's description of $L$. arctica with leaves obtuse at the apex. They have very slender scape-like stems $\mathrm{I}^{\mathrm{cm}}$ high, terminated by a single dark-brown spike, rarely with a second peduncled one; whole plant glabrous; leaves rosulate at the base of the stem, flat and broadly subulate, tapering from the $3^{\mathrm{mm}}$ wide base to the fineness of a hair at the apex, $3^{\mathrm{cm}}$ long.

Tofieldia palustris Huds. Rather common in the sand along the shore on Disco island.

Salix glauca L. Godhavn, Disco.

Some forms of $S$. Grenlandica closely resemble this species.

Salix Gronlandica (And.) Lundstr. Godhavn, Disco ; Wilcox head; Camps 2 and 3.

Specimens of this species showing the greatest variability were collected at nearly all the stations. Eight forms seem to be represented, some of which are quite distinct. Andersson's varieties angustifolia and latifolia were both collected.

Salix Groenlandica leiocarpa (And.) Lundstr. Godhavn, Disco; Wilcox head.

This very distinct form was no. 224 of the Peary Auxiliary Expedition of 1894 .

Salix herbacea L. Wilcox head.

Betula nana L. Godhavn, Disco; Camp 2. Mostly on rocky talus.

Oxyria digyna Hill. Wilcox head; Godhavn.

Polygonum viviparum L. Disco; Devil's Thumb; Camps 2 and 3 ; Wilcox head.

Silene acaulis L. Godhavn, Disco; Camps 2 and 3.

Viscaria alpina Fzl. Disco.

Melandrium triflonum (R. Br.) Vahl. Camp. 2; Wilcox head.

Melandrium involucratum (Ch. \& Schl.) Lange. Disco; Nunatak no. I; Nugsuak peninsula.

Arenaria biflora (L.) Wahl. Godhavn, Disco. 
Ammodenia peploides (L.) Rupr. (var. diffusa Hornem.). Godhavn, Disco.

Alsine longipes (Goldie) Coville. Disco island.

Cerastium alpinum L. (var. lanatum Lindbl.). Godhavn; Devil's Thumb; Camp 3; Wilcox head; Nunatak no. I.

In clefts of rocks; most luxurious where gulls have nested. It is much matted in its growth like our garden chickweed which it much resembles.

Cerastium trigynum Vill. Disco island.

Ranunculus pygmeus Wahl. Godhavn.

Papaver alpinum L. Godhavn; Mt. Schurman; Camp 3; Devil's Thumb; Wilcox head.

Draba crassifolia Graham. Disco island.

Flowers apparently white.

Draba hirta rupestris Hartm. Godhavn; Nunatak no. I; Devil's Thumb.

Draba corymbosa $\mathrm{R}$. Br. Godhavn.

Draba corymbosa grandidentata Lge. Godhavn.

Cardamine bellidifolia L. Mt. Schurman.

Cardamine bellidifolia sinuata J. Vahl. Camp 2 .

Leaves dentate and flowers larger than in the type.

Arabis alpina L. Godhavn. In rich soil.

Arabis alpina glabrata Hartm. Godhavn.

Saxifraga cernua L. Godhavn; Camp 3 ; Nunatak no. I.

Saxifraga rivularis L. Godhavn; Nunatak no. I.

Saxifraga caspitosa L. Disco island; Wilcox head.

Saxifraga caspitosa palmata Hartm. Disco island.

Saxifraga tricuspidata Rottb. Godhavn; Devil's Thumb; Camps 2 and 3 ; Nunatak no. 1 .

Saxifraga comosa (Poir.) Britton. Wilcox head; Camp 3.

Saxifraga nivalis L. Godhavn; Camp. 3.

Saxifraga oppositifolia L. Devil's Thumb. In comparatively well drained soil.

Potentilla rubens Vill. Godhavn.

Potentilla nivea pinnatifida Lehm. Godhavn.

Our specimens seem to be nearer this variety than the type. The plants 
are very large $\left(3^{\mathrm{dm}}\right)$, much branched; flowers cymose ( $18^{\mathrm{mm}}$ diam.), petals one-half longer than the calyx; leaflets 3 (rarely 4 ), tomentose beneath, oblong, pinnately cleft, terminal $2 \cdot 5-3 \cdot 5^{\mathrm{cm}}$ long.

Potentilla Vahliana Lehm. Wilcox head.

Potentilla emarginata Pursh. Camp. 3 ; Mt. Schurman.

Besides the ordinary form a large form was collected on Nunatak no. 1 with very long and slenderly petioled leaves ( $15^{\mathrm{mm}}$ long), terminal portion of the leaf pedicelled (pedicel $3^{-4} 4^{\mathrm{mm}}$ long), acutely and very coarsely incised; stems long and runner-like ( $\left.15-23^{\mathrm{cm}}\right)$.

Sibbaldia procumbens L. Godhavn.

Dryas integrifolia M. Vahl. Godhavn; Camps 2 and 3; Wilcox head.

Alchemilla alpina L. Godhavn.

Empetrum nigrum L. Camps 2 and 3; Devil's Thumb.

Chamanerium angustifolium (L.) Scop. Godhavn.

Chamaenerium latifolium (L.) Sweet. Camp 3; Devil's Thumb.

Chamaenerium latifolium tenuiflorum Fr. Godhavn.

Epilobium alpinum L. Disco island.

Epilobium Hornemanni Reich. Godhavn.

Pyrola rotundifolia pumila Hornem. Camp 3; Devil's Thumb; Godhavn.

Ledum palustre L. (var. decumbens Lange). Disco.

Phyllodoce corrulea (L.) G. \& G. Godhavn; Camp 2.

In rather dry places.

Cassiope tetragona (L.) Don. Camps 2 and 3 ; Mt. Schurman; Disco.

The party used this as material for beds while in camp.

Cassiope hypnoides (L.) Don. Disco; Camps 2 and 3.

Chamacistus procumbens (L.) Kuntze. Camp 2.

Vaccinum uliginosum microphyllum Lge. Camps 2 and 3 ; Mt. Schurman; Godhavn.

Only a single specimen of this was found on Mt. Schurman.

Rhododendron Lapponicum (L.) Wahl. Ice front, Camp 3.

Diapensia Lapponica L. Camps 2 and 3.

Armeria Sibirica Turcz. Disco. 
Pneumaria maritima (L.) Hill. Disco.

Leaves in our plants not glaucous.

Veronica alpina L. Disco island.

Our specimens grade gradually from stout forms with elliptical leaves to slender ones with linear acute leaves.

Bartsia alpina L. Godhavn.

Pedicularis flammea $\mathrm{L}$. Godhavn.

Pedicularis hirsuta L. Godhavn.

Pedicularis Lapponica L. Godhavn.

Campanula rotundifolia Langsdorfiana (A.DC.) Britton. Between Camps 2 and 3 .

Upon face of cliffs.

Campanula uniflora L. Godhavn.

Erigeron uniflorus pulchellus Fr. Godhavn.

Antennaria alpina (L.) Gaertn. Disco ; Camps 2 and 3; Mt. Schurman.

Arnica alpina (L.) Olin. Disco; Camp 2.

Taraxacum officinale Weber. Godhavn.

Artemisia borealis Pall. Godhavn.

Cornell University. 


\section{$2 \mathrm{BHL}$ Biodiversity Heritage Library}

Rowlee, W W and Wiegand, K. M. 1897. "A List of Plants Collected by the Cornell Party on the Peary Voyage of 1896." Botanical gazette 24(6), 417-426. https://doi.org/10.1086/327612.

View This Item Online: https://www.biodiversitylibrary.org/item/94398

DOI: https://doi.org/10.1086/327612

Permalink: https://www.biodiversitylibrary.org/partpdf/222820

\section{Holding Institution}

Missouri Botanical Garden, Peter H. Raven Library

\section{Sponsored by}

Missouri Botanical Garden

\section{Copyright \& Reuse}

Copyright Status: Public domain. The BHL considers that this work is no longer under copyright protection.

This document was created from content at the Biodiversity Heritage Library, the world's largest open access digital library for biodiversity literature and archives. Visit BHL at https://www.biodiversitylibrary.org. 